\title{
Feed Intake and Nutrient Digestibility, Rumen Fermentation Profiles, Milk Yield and Compositions of Lactating Dairy Cows Supplemented by Flemingia macrophylla Pellet
}

\author{
B. Phesatcha ${ }^{a}$, K. Phesatcha ${ }^{b}$, B. Viennaxay ${ }^{c}$, N. T. Thao ${ }^{c, d}$, \& M. Wanapat ${ }^{c, *}$ \\ ${ }^{a}$ Department of Agricultural Technology and Environment, Faculty of Sciences and Liberal Arts, Rajamangala \\ University of Technology Isan, Nakhon Ratchasima, 30000, Thailand \\ bDepartment of Animal Science, Faculty of Agriculture and Technology, Nakhon Phanom University, \\ Nakhon Phanom 48000, Thailand \\ 'Tropical Feed Resources Research and Development Center (TROFREC), Department of Animal Science, Faculty of \\ Agriculture, Khon Kaen University, Khon Kaen 40002, Thailand \\ ${ }^{\mathrm{d} D e p a r t m e n t}$ of Animal Science and Veterinary Medicine, An Giang University, An Giang, 94000, Viet Nam \\ ${ }^{*}$ Corresponding author: metha@kku.ac.th \\ (Received 14-10-2020; Revised 18-12-2020; Accepted 22-12-2020)
}

\begin{abstract}
Feed intake and nutrient digestibility, rumen fermentation profiles, milk yield and compositions of lactating dairy cows fed with Flemingia macrophylla pellet (FMP) were evaluated. Four crossbred dairy cows in early lactation were randomly allocated into a $2 \times 2$ factorial arrangement in a $4 \times 4$ Latin square design (LSD). The first factor was protein level of concentrate mixtures consisted of two levels, i.e., $14 \%$ and $16 \%$. The second factor was supplementation levels of FMP consisted of two levels, i.e., 0 and $150 \mathrm{~g} / \mathrm{cow} / \mathrm{d}$. There were no interactions between the protein level of concentrate and FMP supplementation on feed intake and digestibility, rumen fermentation profiles, milk yield and composition of lactating dairy cows. The findings revealed that both factors significantly impacted feed intakes. They also significantly increased the digestibility of CP and neutral detergent fiber (NDF). Ruminal ammonia nitrogen and propionate $\left(C_{3}\right)$ concentrations were improved $(p<0.05)$, while rumen acetate $\left(C_{2}\right)$, the ratio of $\mathrm{C}_{2}: \mathrm{C}_{3}$, estimated methane $\left(\mathrm{CH}_{4}\right)$ production, and protozoal counts were subsequently reduced $(\mathrm{p}<0.05)$. Crude protein level and FMP supplementation additionally improved nitrogen absorption and utilization, as well as microbial nitrogen synthesis. Milk production was significantly increased by the FMP feeding. In conclusion, a concentrated mixture with $16 \% \mathrm{CP}$ along with supplementation of FMP at a dose of $150 \mathrm{~g} / \mathrm{cow} / \mathrm{d}$ could significantly increase rumen fermentation end-products, microbial protein synthesis, mitigated rumen $\mathrm{CH}_{4}$ production, and milk production in lactating dairy cows fed with rice straw.
\end{abstract}

Keywords: Fodder tree; nutrient digestibility; microbial protein; rumen fermentation; dairy cows

\section{INTRODUCTION}

Fodder trees and shrubs have been attributed to the diversity of livelihood, accounting from N-fixing in soil, firewood, fencings, human vegetables, and onwards to serve as animal feeds (Teferedegne, 2000; Franzel et al., 2014). Their nutritive values, especially the phytonutrients consisting of condensed tannins and saponins, have impacted the end-products of rumen fermentation and ruminant productivity (Wanapat et al., 2012; Wang et al., 2018).

Currently, many attempts have been reported on the potential use of phytonutrients (PTN) to modulate rumen ecology, especially their mode of actions on rumen protozoa and the reduction of methane production (Patra \& Saxena, 2009; Wanapat, 2009; Wanapat et al., 2013). Interestingly, Wang et al. (2018) revealed a remarkable PTN in hazel (Corylus avellana), which de- creased methane production and urinary nitrogen excretion in sheep. Furthermore, Ampapon \& Wanapat (2020) highlighted that PTN could increase rumen propionate production and remarkably mitigated rumen methane production.

Flemingia (Flemingia macrophylla) is an original fodder shrub in the tropics. It contains protein in the range of $16.9 \%$ to $23.7 \%$ CP (Andersson et al., 2006; Viennasay \& Wanapat, 2020) and condensed tannins in the range of $2.4 \%$ to $3.3 \%$ of dry matter (Mui et al., 2001). Fagundes et al. (2020) reported that Flemingia contains condensed tannins at the level of $10.9 \%$ of dry matter. When compared to the other species evaluated, this result indicates that condensed tannin is a natural additive for replacing ionophores to improve ruminal fermentation. Condensed tannins from Flemingia have the ability to alter the rumen fermentation in ruminants. Flemingia leaf was harvested after four months of regrowth and 
was sun-dried and ground to be used as a supplemental powder for beef cattle.

However, it is necessary to investigate their uses, as well as their interactions in the ruminant diet, to increase the end-products of rumen fermentation and milk production. Hence, the aim of this study was to evaluate the effects of supplementation of Flemingia leaf as a feed pellet with different protein levels on dry matter intake, digestibility of nutrients, end-products of rumen fermentation, microbial population, as well as milk yield and quality in lactating crossbred dairy cows fed on rice straw as a roughage source.

\section{MATERIALS AND METHODS}

This experiment was conducted in accordance with the recommendations on care and use of the Animal Care and Use Committee of Khon Kaen University, Thailand (ACUC-KKU 49/2559).

\section{Preparation of Flemingia macrophylla Pellet}

Fresh leaves of Flemingia were harvested and moisture-reduced by sun-drying about 3-5 days and were ground to pass a $1 \mathrm{~mm}$ screen. Flemingia pellet (FMP) was produced by mixing $90 \%$ of dried Flemingia leave, $9 \%$ of cassava chip, and $1 \%$ of molasses, then water was added with a ratio of 0.8:1 (water and meal, respectively). The pellets were processed by using a pellet machine (victor pellet mill, China) and then sun-dried to achieve about $90 \%$ of the dry matter before feeding to the animals. FMP are small cylindrical pieces $10 \mathrm{~mm}$ long with diameters $5 \mathrm{~mm}$.

\section{Animals and Design}

Four multiparous Holstein-Friesian crossbred lactating dairy cows (50\% Holstein-Friesian $\times 50 \%$ Thai native breed) with $410 \pm 5 \mathrm{~kg}$ of body weight (BW) in early lactation were randomly arranged into a $2 \times 2$ factorial arrangement in a $4 \times 4$ Latin square design. The first factor was crude protein level of concentrate mixtures consisted of 2 levels, i.e., $14 \%$ and $16 \%$. The second factor was the concentration of FMP supplementation consisted of two levels, i.e., 0 and $150 \mathrm{~g} / \mathrm{cow} / \mathrm{d}$.

The experimental cows received the diets for four treatments with different protein and FMP supplementations. Ingredient compositions of concentrate mixture and nutrient composition are presented in Table 1. Before the treatments were imposed, the cattle were treated with vitamin $\mathrm{A}_{1} \mathrm{D}_{3}$ and $\mathrm{E}$ and were drenched with anthelmintics prior to the experiment.

This experiment was conducted for 4 consecutive durations with each section of 3 weeks. The first 14 days were used for the adaptation period and for feed dry matter intake measurements, while the last 7 days were for sample collection (feeds, faces, and urine). The cows were fed twice daily at 07.00 and 16.00 o' clock with water and mineral block as a free choice (Mineral block, each $\mathrm{kg}$ of the block contains: Vitamin A: 10,000,000 IU; Vitamin D: 1,600,000 IU; Vitamin E: 70,000 IU; Fe: 50 g;
Mn: 40 g; Zn: 40 g; Cu: 10 g; Co: 0.1 g; Se: 0.1 g; I: 0.5 g.). Concentrates were offered at concentrate supplement to milk yield of 1:2.

\section{Samples Collection and Chemical Analyses}

Feeds and refusals were collected daily during the experimental period and were composited by period prior to chemical analyses. Feeds, fecal, and urine samples were collected during the last seven days of each period. Fecal samples were collected by rectal sampling, whilst urine samples were collected by spot sampling. The urine sample from each cow was collected from in situ manual triggers via vulva. Composited feed samples were oven-dried at $60^{\circ} \mathrm{C}$ and ground $(1 \mathrm{~mm}$ screen using Cyclotech Mill, Tecator, Sweden) and then analyzed for DM, ash, and CP contents (AOAC, 2012) acid insoluble ash (AIA) for determining digestibility as an internal indicator. Using the ANKOM fiber analyzer (ANKOM A200, ANKOM Technology, New York, USA) for determining neutral detergent fiber (NDF), acid detergent fiber (ADF). ADF was analyzed according to an AOAC method (2012) and was expressed inclusive of residual ash, aNDF in samples was estimated according to Van Soest et al. (1991) with addition of $\alpha$-amylase but without sodium sulphite, while acid insoluble ash (AIA) was measured according to Van Keulen \& Young (1977). Content of condensed tannins in FMP was chemically analyzed by using the vanillin- $\mathrm{HCl}$ method, according to Poungchompu et al. (2009).

Collection of milk yield from each cow was done in the morning and in the afternoon of milking times, preserved with potassium dichromate $\left(\mathrm{K}_{2} \mathrm{CR}_{2} \mathrm{O}_{7}\right)$, and stored at $4{ }^{\circ} \mathrm{C}$ until further analysis of milk compositions (protein, fat, lactose, solids-not-fat, and total solids) by an infrared method using Milko-Scan (Foss Electric, Hillerod, Denmark). The concentration of milk urea nitrogen (MUN) was analyzed by using Sigma kits \#640 (Sigma Diagnostics, St. Louis, MO).

On the last day of each experimental period, rumen fluid and blood samples were taken at 0 and 4 hours after the morning feeding. Rumen fluid $(200 \mathrm{~mL})$ was collected from the rumen by a stomach tube connected with a vacuum pump. Rumen fluid was measured for $\mathrm{pH}$ and temperature immediately. Samples of rumen fluid at a volume of $50 \mathrm{~mL}$ were collected and added with $5 \mathrm{~mL}$ of $1 \mathrm{M} \mathrm{H}_{2} \mathrm{SO}_{4}$ to stop the fermentation process of microbial activity and then centrifuged at 16,000 x g for 15 minutes. About $20 \mathrm{~mL}$ of supernatant were collected and frozen at $-20^{\circ} \mathrm{C}$ until later analyzed in the laboratory for analysis of $\mathrm{NH}_{3}-\mathrm{N}$ (Kjeltech Auto 1030 Analyzer, Tecator, Höganäs, Sweden) (AOAC, 2012). The samples of rumen fluid were used for VFAs analysis using High-Performance Liquid Chromatography (HPLC; Model Water 600; UV detector, Millipore Crop; column novapak C18; column size $3.9 \times 300 \mathrm{~mm}$; mobile phase $10 \mathrm{mM} \mathrm{H}_{2} \mathrm{PO}_{4}$ [pH 2.5]) according to the method of Mathew et al. (1997). Estimation of ruminal methane production was conducted based on VFA proportions $\left(\mathrm{CH}_{4}\right.$ production $=0.45$ (acetate) -0.275 (propionate) + 0.4(butyrate) (Moss et al., 2000)). The second part of the 
filtered fluid sample was used for measuring the rumen microbial population, such as bacteria, protozoa, and fungi using the method of Galyean (1989).

Sample of blood from each cow (about $10 \mathrm{~mL}$ ) was collected from a jugular vein at the same time as rumen fluid sampling and was put into tubes containing $12 \mathrm{mg}$ of EDTA, and plasma was separated by centrifugation at $500 \times g$ for 10 minutes (Table Top Centrifuge PLC-02, U.S.A.) and stored at $-20^{\circ} \mathrm{C}$ until analysis of blood urea nitrogen (BUN) (Crocker, 1967). Urinary allantoin was analyzed by the method of Chen et al. (1993). Urinary creatinine concentration was measured by the method of Hawk et al. (1976). The microbial purines retained were further calculated using the equation of Chen \& Gomes (1995) and Galo et al. (2003).

\section{Statistical Analysis}

All data collected were subjected to a $2 \times 2$ factorial arrangement in a $4 \times 4$ Latin square design (LSD) using PROC GLM (SAS, 2013). The statistical parameters included experimental animal, period, protein levels of concentrate, Flemingia pellets, and the interaction of protein levels of concentrate $\times$ Flemingia pellets. All data were statistically compared by Tukey's multiple comparison test according to the method of Crichton (1999).

\section{RESULTS}

\section{Chemical Composition of The Experimental Feeds}

Feed ingredients and chemical compositions of concentrate, rice straw, and FMP used in this experiment are presented in Table 1. Local feed ingredients of the concentrate were mixed, which contained $\mathrm{CP}$ at $14.2 \%$ and $16.5 \%$, respectively. Rice straw contained low $\mathrm{CP}$, i.e., $2.4 \%$. In contrast, FMP contained high $\mathrm{CP}$, i.e., $27.2 \%$. In addition, FMP contained condensed tannins at the level of $5.6 \%$ of dry matter, while concentrate and RS did not contain condensed tannin.

\section{Dry Matter Intake and Nutrients Digestibility}

Protein level and FMP supplementation increased dry matter intake and the digestibility of nutrients (Table 2). There were no interactions between the protein level of concentrate and FMP supplementation on dry matter intake and nutrients digestibility. The level of $\mathrm{CP}$ and FMP supplementation did not affect roughage intake. Intakes of concentrate significantly increased $(\mathrm{p}<0.05)$ with the increased CP level and FMP supplementation $(p<0.05)$. However, there was no interaction effect of CP level and FMP supplementation on the concentrate intake. Total feed intake was not affected by the $\mathrm{CP}$ level and FMP supplementation. Additionally, CP and NDF digestibility were higher $(p<0.05)$ in cows receiving a higher level of CP and FMP supplementation. However, there was no interaction effect of $\mathrm{CP}$ level and FMP supplementation on the CP and NDF digestibility. In addition, $\mathrm{CP}$ level and FMP supplementation did not affect DM and OM digestibility.

\section{Ruminal Parameters, Blood Metabolite, and Protozoa Population}

The rumen parameters, including ruminal $\mathrm{pH}$, ruminal temperature, ruminal $\mathrm{NH}_{3}-\mathrm{N}$, blood urea $\mathrm{N}$, volatile fatty acids, and methane production, are presented

Table 1. Compositions of concentrate mixtures, rice straw, and Flemingia pellet

\begin{tabular}{|c|c|c|c|c|}
\hline \multirow{2}{*}{ Items } & \multicolumn{2}{|c|}{ Concentrate mixtures } & \multirow{2}{*}{ RS } & \multirow{2}{*}{ FMP } \\
\hline & $\mathrm{C} 1$ & $\mathrm{C} 2$ & & \\
\hline \multicolumn{5}{|c|}{ Concentrate ingredients, $\%$ as fresh basis } \\
\hline Cassava chip & 60.0 & 60.0 & & \\
\hline Coconut meal & 15.0 & 19.0 & & \\
\hline Palm meal & 10.0 & 10.0 & & \\
\hline Rice bran & 10.0 & 5.0 & & \\
\hline Urea & 1.5 & 2.5 & & \\
\hline Molasses & 2.0 & 2.0 & & \\
\hline Mineral mixture & 0.5 & 0.5 & & \\
\hline Salt & 0.5 & 0.5 & & \\
\hline Sulfur & 0.5 & 0.5 & & \\
\hline Total & 100.0 & 100.0 & & \\
\hline \multicolumn{5}{|l|}{ Chemical composition } \\
\hline Dry matter, \% & 92.5 & 92.1 & 93.4 & 84.6 \\
\hline & & $---\%$ c & -1----- & \\
\hline Organic matter & 92.6 & 94.7 & 91.6 & 92.3 \\
\hline Ash & 7.4 & 5.3 & 8.4 & 7.7 \\
\hline Crude protein & 14.2 & 16.5 & 2.4 & 27.2 \\
\hline Acid detergent fiber & 14.6 & 15.7 & 52.6 & 31.2 \\
\hline Neutral detergent fiber & 18.7 & 16.8 & 76.2 & 53.1 \\
\hline Condensed tannins & - & - & - & 5.6 \\
\hline
\end{tabular}

Note: $\mathrm{C} 1=$ Concentrate mixture containing $14 \% \mathrm{CP} ; \mathrm{C} 2=$ Concentrate mixture containing $16 \% \mathrm{CP} ; \mathrm{RS}=$ rice straw; FMP= Flemingia pellet. 
Table 2. Voluntary feed intake and nutrient digestibility in dairy cows affected by protein level and Flemingia pellet (FMP) supplementation

\begin{tabular}{|c|c|c|c|c|c|c|c|c|}
\hline \multirow{3}{*}{$\begin{array}{c}\text { Variables } \\
\text { FMP (g/cow/d) }\end{array}$} & \multicolumn{4}{|c|}{ Treatments } & \multirow{3}{*}{ SEM } & \multirow{2}{*}{\multicolumn{3}{|c|}{ p-value }} \\
\hline & \multicolumn{2}{|c|}{$\mathrm{C} 1$} & \multicolumn{2}{|c|}{$\mathrm{C} 2$} & & & & \\
\hline & FMP-0 & FMP-150 & FMP-0 & FMP-150 & & $\mathrm{C}$ & FMP & $\mathrm{C} \times \mathrm{FMP}$ \\
\hline \multicolumn{9}{|l|}{ Dry matter intake } \\
\hline \multicolumn{9}{|l|}{ Roughage intake } \\
\hline $\mathrm{kg} /$ day & 5.5 & 5.6 & 5.5 & 5.6 & 0.16 & 0.291 & 0.330 & 0.721 \\
\hline$\%$ of BW & 1.5 & 1.6 & 1.4 & 1.6 & 0.08 & 0.686 & 0.457 & 0.463 \\
\hline g/kg BW0.75 & 66.9 & 70.2 & 64.5 & 70.6 & 0.76 & 0.632 & 0.723 & 0.759 \\
\hline \multicolumn{9}{|l|}{ Concentrate intake } \\
\hline kg/day & 5.5 & 6.4 & 5.5 & 6.5 & 0.31 & 0.033 & 0.042 & 0.558 \\
\hline$\%$ of BW & 1.5 & 1.7 & 1.5 & 1.8 & 0.08 & 0.026 & 0.047 & 0.703 \\
\hline g/kg BW0.75 & 66.4 & 67.5 & 64.5 & 67.6 & 1.67 & 0.031 & 0.516 & 0.775 \\
\hline \multicolumn{9}{|l|}{ Total feed intake } \\
\hline $\mathrm{kg} /$ day & 11.0 & 12.0 & 11.0 & 12.1 & 0.06 & 0.678 & 0.728 & 0.834 \\
\hline$\%$ of BW & 3.0 & 3.3 & 2.9 & 3.4 & 0.07 & 0.501 & 0.032 & 0.727 \\
\hline g/kg BW0.75 & 133.3 & 137.7 & 129.0 & 138.2 & 3.34 & 0.580 & 0.041 & 0.653 \\
\hline \multicolumn{9}{|l|}{ Nutrient digestibility, \% } \\
\hline Dry matter & 66.5 & 67.4 & 67.8 & 69.6 & 1.27 & 0.408 & 0.678 & 0.552 \\
\hline Organic matter & 62.4 & 63.1 & 61.1 & 64.6 & 2.51 & 0.621 & 0.515 & 0.545 \\
\hline Crude protein & 46.4 & 54.3 & 58.4 & 63.1 & 0.74 & 0.023 & 0.049 & 0.708 \\
\hline Neutral detergent fiber & 41.3 & 45.7 & 50.1 & 55.2 & 0.89 & 0.047 & 0.015 & 0.951 \\
\hline Acid detergent fiber & 44.6 & 47.2 & 42.1 & 47.6 & 1.11 & 0.360 & 0.139 & 0.796 \\
\hline
\end{tabular}

Note: FMP-0= unsupplementation Flemingia pellet; FMP-150= supplementation Flemingia pellet at 150g/cow/d; C1= Concentrate mixture containing $14 \% \mathrm{CP} ; \mathrm{C} 2=$ Concentrate mixture containing $16 \% \mathrm{CP} ; \mathrm{BW}=$ body weight; $\mathrm{SEM}=$ standard error of the mean.

Table 3. Fermentation characteristics and blood urea nitrogen in dairy cows affected by protein level and Flemingia pellet (FMP) supplementation

\begin{tabular}{|c|c|c|c|c|c|c|c|c|}
\hline \multirow{3}{*}{$\begin{array}{c}\text { Variables } \\
\text { FMP (g/cow/d) }\end{array}$} & \multicolumn{4}{|c|}{ Treatments } & \multirow{3}{*}{ SEM } & \multirow{2}{*}{\multicolumn{3}{|c|}{$\mathrm{p}$-value }} \\
\hline & \multicolumn{2}{|c|}{$\mathrm{C} 1$} & \multicolumn{2}{|c|}{$\mathrm{C} 2$} & & & & \\
\hline & FMP-0 & FMP-150 & FMP-0 & FMP-150 & & $\mathrm{C}$ & FMP & $\mathrm{C} \times \mathrm{FMP}$ \\
\hline Ruminal pH & 6.7 & 6.8 & 6.5 & 6.8 & 0.18 & 0.775 & 0.249 & 0.463 \\
\hline Temperature, ${ }^{\circ} \mathrm{C}$ & 38.6 & 39.0 & 39.0 & 39.3 & 0.22 & 0.341 & 0.305 & 0.221 \\
\hline $\mathrm{NH}_{3}-\mathrm{N}, \mathrm{mg} / \mathrm{dL}$ & 11.3 & 13.6 & 12.4 & 14.9 & 0.30 & 0.028 & 0.015 & 0.659 \\
\hline BUN, mg/dL & 10.1 & 10.5 & 11.7 & 12.1 & 0.86 & 0.543 & 0.612 & 0.802 \\
\hline Total VFAs, $\mathrm{mmol} / \mathrm{L}$ & 107.4 & 108.1 & 105.3 & 107.2 & 1.35 & 0.351 & 0.359 & 0.726 \\
\hline \multicolumn{9}{|l|}{ VFAs, mol/100mol } \\
\hline Acetic acid $\left(\mathrm{C}_{2}\right)$ & 69.4 & 65.1 & 67.5 & 62.4 & 1.18 & 0.024 & 0.015 & 0.908 \\
\hline Propionic acid $\left(\mathrm{C}_{3}\right)$ & 21.3 & 24.7 & 22.5 & 26.2 & 0.26 & 0.015 & 0.014 & 0.423 \\
\hline Butyric acid $\left(\mathrm{C}_{4}\right)$ & 9.3 & 10.2 & 10.0 & 11.4 & 0.37 & 0.678 & 0.779 & 0.706 \\
\hline $\mathrm{C}_{2}: \mathrm{C}_{3}$ & 3.3 & 2.6 & 3.0 & 2.4 & 0.31 & 0.611 & 0.248 & 0.658 \\
\hline $\mathrm{CH}_{4}(\mathrm{mM})$ & 29.1 & 26.6 & 28.2 & 25.4 & 0.25 & 0.013 & 0.015 & 0.091 \\
\hline
\end{tabular}

Note: FMP-0= unsupplementation Flemingia pellet; FMP-150= supplementation Flemingia pellet at 150g/cow/d; C1= Concentrate mixture containing $14 \% \mathrm{CP} ; \mathrm{C} 2=$ Concentrate mixture containing $16 \% \mathrm{CP} ; \mathrm{SEM}=$ standard error of the mean; $\mathrm{NH}_{3}-\mathrm{N}=$ ammonia nitrogen; $\mathrm{BUN}=$ blood urea nitrogen; VFAs= volatile fatty acids; $\mathrm{CH}_{4}=$ methane production= $0.45\left(\mathrm{C}_{2}\right)-0.275\left(\mathrm{C}_{3}\right)+0.4\left(\mathrm{C}_{4}\right)$ calculated according to Moss et al. $(2000)$.

in Table 3. There were no interactions between the protein level of concentrate and FMP supplementation on ruminal parameters, blood metabolite, and protozoa population. The results showed that ruminal $\mathrm{pH}$ and ruminal temperature were not affected by the level of $\mathrm{CP}$ and FMP supplementation. However, an increased level of $\mathrm{CP}$ and FMP supplementation significantly increased ruminal $\mathrm{NH}_{3}-\mathrm{N}$ concentration $(\mathrm{p}<0.05)$. There was no interaction effect of CP level and FMP supplementation on ruminal $\mathrm{NH}_{3}-\mathrm{N}$. Level of $\mathrm{CP}$ and FMP supplementation did not affect BUN concentration. Level of $\mathrm{CP}$ and FMP supplementation had no significant effect on total VFAs, butyric acid, and the ratio of acetic acid to propionic acid concentrations. Propionic acid was increased, but acetic acid and methane production were decreased $(\mathrm{p}<0.05)$ with the increased CP level and FMP supplementation. However, there was no interaction effect of CP level and FMP supplementation on the acetic acid, 
propionic acid, and methane production. In addition, the bacterial and fungal zoospores population were similar in cows receiving the increased levels of $\mathrm{CP}$ and FMP supplementation (Table 4). Interestingly, protozoal rumen count decreased with FMP feeding $(p<0.05)$, while it was not affected by crude protein levels in the concentrate mixture.

\section{Microbial Protein Synthesis}

As shown in Table 5, there were no interactions between the protein level of concentrate and FMP supplementation on microbial nitrogen synthesis (MNS). Microbial nitrogen synthesis and efficiency of microbial nitrogen synthesis (EMNS) were increased in dairy cows receiving high protein levels of concentrate mixture with FMP supplementation $(\mathrm{p}<0.05)$. However, there was no interaction effect of $\mathrm{CP}$ level and FMP supplementation on MNS and EMNS.

\section{Dairy Milk Production and Compositions}

There were no interactions between the protein level of concentrate and FMP supplementation on milk yield and compositions. Milk yield and 3.5\% FCM production were increased by the increased crude protein levels and FMP supplementation (Table 6). However, there was no interaction effect of CP level and FMP supplementation on the milk yield. However, there was a significant interaction effect of CP level and FMP supplementation on the $3.5 \%$ FCM production. Cows fed mixed concentrate with $16 \%$ CP with FMP supplementation did not significantly affect 3.5\% FCM milk production. The highest value was found in dairy cows that were fed at 16\% CP $(\mathrm{p}<0.05)$. Moreover, milk compositions, including milk fat, milk protein, lactose, solids-not-fat, total solids, and milk urea nitrogen, were similar among treatments by crude protein levels and FMP supplementation.

\section{DISCUSSION}

\section{Chemical Composition of The Experimental Diets}

The dietary CP content of Flemingia hay meal was $27.2 \% \mathrm{DM}$ and was slightly higher than the figure presented by Phesatcha et al. (2016) but was higher than the result of Mui et al. (2001). Fagundes et al. (2014) suggested that Flemingia harvested in the dry season would have lower $\mathrm{CP}$ and higher condensed tannins content. The nutritive value of Flemingia leaf would be influenced by the growth stage, the season of harvesting, and soil content where it was grown. Under this study, at this value, it can be taken as a high level for fodder shrub.

\section{Dry Matter Consumption and Nutrient Digestibility}

The results revealed the increased concentrate intake and total DM intake by the increased crude protein level with FMP supplementation. Flemingia supplementation at this level did not adversely affect total feed intake. However, a higher level of FMP supplementation might stimulate the intake of roughage. An important limitation of feed with high tannin content in the use of ruminant feed is its low palatability that may restrict feed intake.

Table 4. Microbial population in dairy cows affected by protein level and Flemingia pellet (FMP) supplementation

\begin{tabular}{|c|c|c|c|c|c|c|c|c|}
\hline \multirow{3}{*}{$\begin{array}{c}\text { Variables } \\
\text { FMP (g/cow/d) }\end{array}$} & \multicolumn{4}{|c|}{ Treatments } & \multirow{3}{*}{ SEM } & \multirow{2}{*}{\multicolumn{3}{|c|}{ p-value }} \\
\hline & \multicolumn{2}{|c|}{$\mathrm{C} 1$} & \multicolumn{2}{|c|}{$\mathrm{C} 2$} & & & & \\
\hline & FMP-0 & FMP-150 & FMP-0 & FMP-150 & & $\mathrm{C}$ & FMP & $\mathrm{C} \times \mathrm{FMP}$ \\
\hline \multicolumn{9}{|l|}{ Ruminal microbes, } \\
\hline Bacteria, $x 10^{11} \mathrm{cell} / \mathrm{ml}$ & 4.8 & 5.4 & 5.0 & 5.7 & 0.24 & 0.654 & 0.245 & 0.702 \\
\hline Protozoa, $\times 10^{6}$ cell $/ \mathrm{ml}$ & 8.9 & 7.6 & 10.9 & 9.4 & 0.31 & 0.167 & 0.027 & 0.681 \\
\hline Fungi, $\times 10^{5} \mathrm{cell} / \mathrm{ml}$ & 3.2 & 3.1 & 2.9 & 2.8 & 0.35 & 0.751 & 0.869 & 0.639 \\
\hline
\end{tabular}

Note: FMP-0= unsupplementation Flemingia pellet; FMP-150= supplementation Flemingia pellet at 150g/cow/d; C1= Concentrate mixture containing $14 \% \mathrm{CP} ; \mathrm{C} 2=$ Concentrate mixture containing $16 \% \mathrm{CP}$; SEM= standard error of the mean.

Table 5. Urinary purine derivatives (PD) and microbial protein synthesis in dairy cows affected by protein level and Flemingia pellet (FMP) supplementation

\begin{tabular}{|c|c|c|c|c|c|c|c|c|}
\hline \multirow{3}{*}{$\begin{array}{c}\text { Variables } \\
\text { FMP (g/cow/d) }\end{array}$} & \multicolumn{4}{|c|}{ Treatments } & \multirow{3}{*}{ SEM } & \multirow{2}{*}{\multicolumn{3}{|c|}{$\mathrm{p}$-value }} \\
\hline & \multicolumn{2}{|c|}{$\mathrm{C} 1$} & \multicolumn{2}{|c|}{$\mathrm{C} 2$} & & & & \\
\hline & FMP-0 & FMP-150 & FMP-0 & FMP-150 & & $\mathrm{C}$ & FMP & $\mathrm{C} \times \mathrm{FMP}$ \\
\hline \multicolumn{9}{|c|}{$\begin{array}{l}\text { Urinary purine derivatives } \\
(\mathrm{mmol} / \mathrm{d})\end{array}$} \\
\hline Allantoin excretion & 149.5 & 179.9 & 167.4 & 179.4 & 4.39 & 0.013 & 0.016 & 0.509 \\
\hline Allantoin absorption & 102.7 & 128.5 & 114.8 & 148.5 & 2.14 & 0.015 & 0.028 & 0.084 \\
\hline MNS (gN/d) & 74.6 & 86.4 & 81.5 & 95.7 & 2.03 & 0.041 & 0.012 & 0.751 \\
\hline EMNS (g/kg OMDR) & 25.5 & 31.1 & 30.6 & 36.1 & 1.06 & 0.056 & 0.013 & 0.246 \\
\hline
\end{tabular}

Note: FMP-0= unsupplementation Flemingia pellet; FMP-150= supplementation Flemingia pellet at 150g/cow/d; C1= Concentrate mixture containing $14 \% \mathrm{CP} ; \mathrm{C} 2=$ Concentrate mixture containing $16 \% \mathrm{CP}$; SEM= standard error of the mean; MNS= efficiency of nitrogen synthesis; EMNS= efficiency of microbial nitrogen synthesis; $\mathrm{OMDR}=$ digestible organic matter apparently fermented in the rumen. 
Table 6. Milk production and chemical composition in dairy cows affected by protein level and Flemingia pellet (FMP) supplementation

\begin{tabular}{|c|c|c|c|c|c|c|c|c|}
\hline \multirow{3}{*}{$\begin{array}{c}\text { Variables } \\
\text { FMP }(\mathrm{g} / \mathrm{cow} / \mathrm{d})\end{array}$} & \multicolumn{4}{|c|}{ Treatments } & \multirow{3}{*}{ SEM } & \multirow{2}{*}{\multicolumn{3}{|c|}{ p-value }} \\
\hline & \multicolumn{2}{|c|}{$\mathrm{C} 1$} & \multicolumn{2}{|c|}{$\mathrm{C} 2$} & & & & \\
\hline & FMP-0 & FMP-150 & FMP-0 & FMP-150 & & $\mathrm{C}$ & FMP & $\mathrm{C} \times \mathrm{FMP}$ \\
\hline Milk yield, kg/cow/d & 10.1 & 11.4 & 12.7 & 13.1 & 0.22 & 0.014 & 0.033 & 0.801 \\
\hline $3.5 \%$ FCM, kg/cow $/ \mathrm{d}$ & 9.9 & 11.6 & 13.5 & 13.5 & 0.23 & 0.011 & 0.042 & 0.036 \\
\hline \multicolumn{9}{|l|}{ Milk composition, \% } \\
\hline Protein & 3.0 & 3.2 & 3.4 & 3.6 & 0.01 & 0.235 & 0.358 & 0.773 \\
\hline Fat & 3.4 & 3.5 & 3.6 & 3.7 & 0.03 & 0.378 & 0.096 & 0.305 \\
\hline Lactose & 4.7 & 4.4 & 4.8 & 4.8 & 0.16 & 0.752 & 0.293 & 0.441 \\
\hline Solids-not-fat & 8.4 & 8.2 & 8.9 & 9.1 & 0.21 & 0.766 & 0.828 & 0.698 \\
\hline Total solids & 11.8 & 11.7 & 12.5 & 12.8 & 0.31 & 0.947 & 0.901 & 0.523 \\
\hline Milk urea nitrogen, mg/dL & 10.3 & 10.9 & 11.6 & 12.4 & 1.35 & 0.702 & 0.497 & 0.920 \\
\hline
\end{tabular}

Note: FMP-0= unsupplementation Flemingia pellet; FMP-150= supplementation Flemingia pellet at 150g/cow/d; C1= Concentrate mixture containing $14 \% \mathrm{CP} ; \mathrm{C} 2=$ Concentrate mixture containing $16 \% \mathrm{CP} ; \mathrm{SEM}=$ standard error of the mean; $3.5 \% \mathrm{FCM}=3.5 \%$ fat corrected milk [the equation: $(0.432$ $\mathrm{x} \mathrm{kg}$ of milk $)+(\mathrm{kg}$ of fat $x 16.23)]$.

However, Patra \& Saxena (2011) reported that condensed tannin supplementation in the diet would bind dietary proteins in the rumen, slow down protein degradation, and reduce nitrogen losses that eventually increase protein utilization in the lower gut. Patra \& Saxena (2011) reported that $3 \%-6 \%$ of condensed tannins in the diets would not affect rumen fermentation and productivity. Barry \& Manley (1984) confirmed a higher protein outflow into the lower gut when the sheep were fed with L. pedunculatus due to the effect of the rumen proteintannins complex. Gunun et al. (2016) reported the supplementation of Antidesma thwaitesianum Muell. Arg. seed meal, which consisted of condensed tannins, did not change the dry matter intakes. Conversely, Cieslak et al. (2016) stated that using tannin extracts from Sanguisorba plant $(100 \mathrm{mg})$ could reduce $(25.6 \%)$ the in vitro dry matter digestibility. Essentially, the level of supplementation was an important factor in raising an impact on rumen fermentation.

\section{Ruminal Parameters, Blood Metabolite, and Microbial Population}

The ruminal $\mathrm{pH}$ values were stable at 6.5 to 6.6 , and the ruminal temperature was found at $38.6^{\circ} \mathrm{C}$ to $39.1^{\circ} \mathrm{C}$. Wanapat \& Pimpa (1999) stated that optimal ammonia nitrogen concentration (15-30 $\mathrm{mg} / \mathrm{dL})$ in the ruminal fluid would support microbial growth and microbial activity. However, condensed tannins have a high capacity for protein binding in the rumen and reduce dietary proteins lose by ammonia production, thus improving protein utilization.

Moreover, BUN and milk urea nitrogen (MUN) under the present study were not affected by feed supplementation and were closer to the normal range. Viennaxay et al. (2020) reported that balanced diets for lactating dairy cows were associated with an average BUN concentration of $15 \mathrm{mg} / \mathrm{dL}$ and average MUN concentration of $5 \mathrm{mg} / \mathrm{dL}$ to $16 \mathrm{mg} / \mathrm{dL}$ (Jonker et al., 1999; Satter \& Slyter, 1974). According to this study, concentrations of BUN and MUN were 10.1 to $12.1 \mathrm{mg} / \mathrm{dL}$ and 10.3 to $12.4 \mathrm{mg} / \mathrm{dL}$, respectively.
In the rumen, condensed tannins may directly inhibit the growth of methanogens as was reported by other researchers (Patra \& Saxena, 2010). Additionally, tannins can reduce enteric methane production. Hence they were important for mitigating greenhouse gas emissions by ruminants (Makkar, 2003). Poungchompu et al. (2009) \& Tavendale et al. (2005) demonstrated that condensed tannins and saponins could lower the protozoal population and maintained fungi zoospore in ruminants that eventually reduced rumen methane production. Russell et al. (2009) stated the positive association of ruminal microorganism numbers to feed digestibility, which plays a significantly vital role in feed-substrate degradation, particularly with bacteria and fungi. The protozoal population was reduced when supplemented with FMP containing condensed tannins. This reduction could be due to the effect of condensed tannins, which may inhibit the growth or activity of ruminal protozoa by binding the proteins and enzymes of a protozoal cell, hence blocking nutrient transport. Furthermore, condensed tannins have a potent anti-protozoal activity by forming complexes with sterols in the protozoal cell membranes (Liu et al., 2011). A reduction of methane from FMP supplementation could be due to the effect of the condensed tannins. Hristov et al. (2013) reported that condensed tannins suppressed methane production, reduced protozoal population, and modulated volatile fatty acids.

\section{Microbial Protein Synthesis}

Rumen ammonia-N derived from the protein degradation would be incorporated for microbial protein synthesis (Karsli \& Russell, 2001). Nitrogen absorption and N-retention were good indicators of nutrient utilization in the ruminants (Chen \& Gomes, 1995). Firkins et al. (2007) showed the rumen microbial protein synthesis was the effective indicator of nitrogen utilization. Furthermore, a close relationship between protein and carbohydrate is essential for effective utilization. Based on this experiment, no significant changes between the two levels of $14 \%$ and $16 \% \mathrm{CP}$ in the concentrate mix- 
tures were obtained, while FMP addition significantly improved the EMNS. Supplementation of FMP at $150 \mathrm{~g} /$ cow/day greatly improved $\mathrm{N}$ absorption and $\mathrm{N}$ retention. $\mathrm{N}$ retention is considered to be the most common index of the protein nutrition status of ruminants. Meanwhile, condensed tannin at a lower level has been reported to have a positive influence or increased $\mathrm{N}$ retention in ruminants (Ahnert et al., 2015). The FMP could have rendered more protein available for digestion in the lower-gut that eventually increased microbial protein, as well as the positive effect of the pellet, which contained condensed tannins. In spite of this result, higher FMP supplementation could be more effective in microbial protein synthesis. The effect of FMP supplementation on reducing rumen protozoal population counts significantly impacted N-recycling and improved over-turn of microbial protein synthesis. Therefore, reducing protozoal populations could improve dietary $\mathrm{N}$ utilization and increase MPS flow to the lower gut (Wang et al., 2012).

\section{Milk Yield and Compositions}

It has been established that good quality roughages would be necessary to provide nutrients for good milk yield and composition (Weiss et al., 2009; KrämerSchmid et al., 2016). A number of researchers have revealed the positive effects of plants and fruit pellets containing phytonutrients such as condensed tannins, which resulted in a remarkable enhancement of rumen feed degradation, nutrient digestibility, and milk yield, as were shown by Norrapoke et al. (2012) and Ampapon et al. (2020). Nevertheless, based on the data shown by Benchaar et al. (2008) and Holtshausen et al. (2009), it was demonstrated the remarkable impacts of PTN when available at a lower level. The FMP supplementation at $150 \mathrm{~g} / \mathrm{cow} / \mathrm{d}$ has exhibited a positive impact on milk yield. Outstandingly, the protein level and the FMP supplementation have shown a synergistic effect, attributed to FMP supplementation on the lower protein level of feed, especially the concentrate mixture. Nevertheless, more research investigations are highly recommended in lactating cows in order to obtain more insightful data.

\section{CONCLUSION}

Based on the present experiment, protein level and FMP supplementation had significant effects on the efficiency of nutrients utilization, by-products of rumen fermentation, and milk yield in lactating dairy cows. Therefore, the protein level of $16 \%$ CP and FMP supplementation at $150 \mathrm{~g} / \mathrm{cow} / \mathrm{d}$ significantly improved rumen fermentation efficiency and milk yield in lactating dairy cows.

\section{CONFLICT OF INTEREST}

Metha Wanapat serves as an editor of the Tropical Animal Science Journal, but has no role in the decision to publish this article. We also certify that there is no conflict of interest with any financial, personal, or other relationships with other people or organization related to the material discussed in the manuscript.

\section{ACKNOWLEDGEMENT}

The authors would like to express our sincere thanks to the Tropical Feed Resources Research and Development Center (TROFREC), Department of Animal Science, Faculty of Agriculture, Khon Kaen University, Dairy Farming Promotion Organization of Thailand (DPO)-North East and Thailand Research Fund (TRF) through the 16th Royal Golden Jubilee PhD Program (contact grant PHD /0019/2556) for providing financial support for the research and the use of the research facilities.

\section{REFERENCES}

Ahnert, S., U. Dickhoefer, F. Schulz, \& A. Susenbeth. 2015. Influence of ruminal Quebracho tannin extract infusion on apparent nutrient digestibility, nitrogen balance and urinary purine derivatives excretion in heifers. Livest. Sci. 177:63-70. https://doi.org/10.1016/j.livsci.2015.04.004

Ampapon, T. \& M. Wanapat. 2019. Rambutan fruit peel powder and dietary protein level influencing on fermentation characteristics, nutrient digestibility, ruminal microorganisms and gas production using in vitro fermentation techniques. Trop. Anim. Health Prod. 51:1489-1496. https://doi. org/10.1007/s11250-019-01837-x

Anantasook, N., M. Wanapat, A. Cherdthong, \& P. Gunun. 2015. Effect of tannins and saponins in Samanea saman on rumen environment, milk yield and milk composition in lactating dairy cows. J. Anim. Physiol. Anim. Nutr. 99:335344. https://doi.org/10.1111/jpn.12198

Andersson, M. S., M. Peters, R. Schultze-Kraft, L. H. FRANCO, \& C. E. Lascano. 2006. Phenological, agronomic and forage quality diversity among germplasm accessions of the tropical legume shrub Cratylia argentea. J. Agric. Sci. 144:237248. https://doi.org/10.1017/S0021859606006034

AOAC. 2012. Official Methods of Analysis of AOAC International. $19^{\text {th }}$ ed. Association of Official Analytical Chemists, Arlington.

Barry, T. N. \& T. R. Manley. 1984. The role of condensed tannins in the nutritional value of Lotus pedunculatus for sheep: 2 . Quantitative digestion of carbohydrates and proteins. Br. J. Nutr. 51:493-504. https://doi.org/10.1079/BJN19840055

Benchaar, C., T. A. McAllister, \& P. Y. Chouinard. 2008. Digestion, ruminal fermentation, Ciliate protozoal populations, and milk production from dairy cows fed Cinnamaldehyde, quebracho condensed tannin, or Yucca schidigera saponin extracts. J. Dairy Sci. 91:4765-4777. https:// doi.org/10.3168/jds.2008-1338

Burns, R. E. 1971. Method for estimation of tannin in grain sorghum 1. Agron. J. 63:511-512. https://doi.org/10.2134/agro nj1971.00021962006300030050x

Chen, X. B., D. J. Kyle, \& E. R. Ørskov. 1993. Measurement of allantoin in urine and plasma by high-performance liquid chromatography with pre-column derivatization. J. Chromatogr. B Biomed. Sci. Appl. 617:241-247.

Chen, X. B. \& M. J. Gomes. 1995. Estimation of Microbial Protein Supply to Sheep and Cattle Based on Urinary Excretion of Purine Derivative-An Overview of 215 the Technique Details. Occasional Publication 1992. International Feed Resources Unit, Rowett Research Institute, Aberdeen, UK.

Cieslak, A., P. Zmora, A. Matkowski, I. Nawrot-Hadzik, E. PersKamczyc, M. El-Sherbiny, M. Bryszak, M. SzumacherStrabe. 2016. Tannins from Sanguisorba officinalis affect 
in vitro rumen methane production and fermentation. J. Anim. Plant Sci. 26:54-62.

Crichton, N. 1999. Information point: Tukey multiple comparison test. J. Clin. Nurs. 8:299-304.

Crocker, C.L. 1967. Rapid determination of urea nitrogen in serum or plasma without deproteinization. Am. J. Med. Technol. 33:361-365.

Dschaak, C. M., C. M. Williams, M. S. Holt, J. S. Eun, A. J. Young, \& B. R. Min. 2011. Effects of supplementing condensed tannin extract on intake, digestion, ruminal fermentation, and milk production of lactating dairy cows. J. Dairy Sci. 94:2508-2519. https://doi.org/10.3168/ jds.2010-3818

Fagundes, G. M., E. C. Modesto, C. E. M. Fonseca, H. R. P. Lima, \& J. P. Muir. 2014. Intake, digestibility and milk yield in goats fed Flemingia macrophylla with or without polyethylene glycol. Small Rumin. Res. 116:88-93. https:// doi.org/10.1016/j.smallrumres.2013.10.018

Fagundes, G. M., G. Benetel, K. C. Santos, K. C. Welter, F. A. Melo, J. P. Muir, \& I. C. S. Bueno. 2020. Tannin-Rich Plants as Natural Manipulators of Rumen Fermentation in the Livestock Industry. Molecules. 25:2943. https://doi. org/10.3390/molecules25122943

Firkins, J. L., Z. Yu, \& M. Morrison. 2007. Ruminal nitrogen metabolism: Perspectives for integration of microbiology and nutrition for dairy. J. Dairy Sci. 90:E1-E16. https://doi. org/10.3168/jds.2006-518

Franzel, S., S. Carsan, B. Lukuyu, J. Sinja, \& C. Wambugu. 2014. Fodder trees for improving livestock productivity and smallholder livelihoods in Africa. Curr. Opin. Environ. Sustain. 6:98-103. https://doi.org/10.1016/j. cosust.2013.11.008

Galo, E., S. M. Emanuele, C. J. Sniffen, J. H. White, \& J. R. Knapp. 2003. Effects of a polymer-coated urea product on nitrogen metabolism in lactating Holstein dairy cattle. J. Dairy Sci. 86:2154-2162. https://doi.org/10.3168/jds. S0022-0302(03)73805-3

Galyean, M. 1989. Laboratory procedure in Animal Nutrition Research. Department of Animal and Range Science. New Mexico State University, USA. p. 188.

Gunun, P., M. Wanapat, N. Anantasook, \& A. Cherdthong. 2016. Effects of condensed tannins in Mao (Antidesma thwaitesianum Muell: Arg.) seed meal on rumen fermentation characteristics and nitrogen utilization in goats. Asian-Australas. J. Anim. Sci. 29:1111-1119. https://doi. org/10.5713/ajas.15.0552

Hawk, P. B., B. L. Oser, \& W. H. Summerson. 1976. Practical Physiological Chemistry, 14th ed. McGraw Hill Publishing Company Ltd., London, UK.

Holtshausen, L., A. V. Chaves, K. A. Beauchemin, S. M. McGinn, T. A. McAllister, N. E. Odongo, P. R. Cheeke, \& C. Benchaar. 2009. Feeding saponin-containing Yucca schidigera and Quillaja saponaria to decrease enteric methane production in dairy cows. J. Dairy Sci. 92:2809-2821. https://doi.org/10.3168/jds.2008-1843

Hristov, A. N., J. Oh, J. L. Firkins, J. Dijkstra, E. Kebreab, G. Waghorn, H. P. S. Makkar, A. T. Adesogan, W. Yang, W. Lee, P. J. Gerber, B. Henderson, J. M. Tricarico. 2013. Mitigation of methane and nitrous oxide emissions from animal operations: I. A review of enteric methane mitigation options. J. Anim. Sci. 91:5045-5069. https://doi. org/10.2527/jas.2013-6585

Jonker, J. S., R. A. Kohn, \& R. A. Erdman. 1999. Milk urea nitrogen target concentrations for lactating dairy cows fed according to national research council recommendations. J. Dairy Sci. 82:1261-1273. https://doi.org/10.3168/jds. S0022-0302(99)75349-X

Karsli, M. A. \& J. R. Russell. 2001. Effects of some dietary factors on ruminal microbial protein synthesis. Turk. J. Vet.
Anim. Sci. 25:681-686.

Krämer-Schmid, M., P. Lund, \& M. R. Weisbjerg. 2016. Importance of NDF digestibility of whole crop maize silage for dry matter intake and milk production in dairy cows. Anim. Feed Sci. Technol. 219:68-76. https://doi. org/10.1016/j.anifeedsci.2016.06.007

Liu, H., V. Vaddella, \& D. Zhou. 2011. Effects of chestnut tannins and coconut oil on growth performance, methane emission, ruminal fermentation, and microbial populations in sheep. J. Dairy Sci. 94:6069-6077. https://doi. org/10.3168/jds.2011-4508

Makkar, H. P. 2003. Effect and fate of tannins in ruminant animals, adaptation to tannins, and strategies to overcome detrimental effects of feeding tannin rich feeds. Small Rumin. Res. 49:241-256. https://doi.org/10.1016/ S0921-4488(03)00142-1

Mathew, S., S. Sagatheman, J. Thomas, \& G. Mathen. 1997. An HPLC method for estimation of volatile fatty acids of ruminal fluid. Ind. J. Anim. Sci. 67:805-807.

McMahon, L. R., T. A. McAllister, B. P. Berg, W. Majak, S. N. Acharya, J. D. Popp, B. E. Coulman, Y. Wang, \& K. J. Cheng. 2000. A review of the effects of forage condensed tannins on ruminal fermentation and bloat in grazing cattle. Can. J. Plant Sci. 80:469-485. https://doi.org/10.4141/ P99-050

Moss, A. R., J. P. Jouany, \& J. Newbold. 2000. Methane production by ruminants: Its contribution to global warming. Ann. Zootech. 49:231-253. https://doi.org/10.1051/ animres:2000119

Mui, N. T., I. Ledin, P. Udén, \& D. Van Binh. 2001. Effect of replacing a rice bran-soya bean concentrate with Jackfruit (Artocarpus heterophyllus) or Flemingia (Flemingia macrophylla) foliage on the performance of growing goats. Livest. Prod. Sci. 72:253-262. https://doi.org/10.1016/ S0301-6226(01)00223-8

Norrapoke, T., M. Wanapat, \& S. Wanapat. 2012. Effects of protein level and mangosteen peel pellets (Mago-pel) in concentrate diets on rumen fermentation and milk production in lactating dairy crossbreds. Asian-Australas. J. Anim. Sci. 25:971. https://doi.org/10.5713/ajas.2012.12053.

Patra, A. K. \& J. Saxena. 2009. The effect and mode of action of saponins on the microbial populations and fermentation in the rumen and ruminant production. Nutr. Res. Rev. 22:204-219. https://doi.org/10.1017/S0954422409990163

Patra, A. K. \& J. Saxena. 2010. A new perspective on the use of plant secondary metabolites to inhibit methanogenesis in the rumen. Phytochemistry. 71:1198-1222. https://doi.org/10.1016/j.phytochem.2010.05.010

Patra, A. K. \& J. Saxena. 2011. Exploitation of dietary tannins to improve rumen metabolism and ruminant nutrition. J. Sci. Food Agric. 91:24-37. https://doi.org/10.1002/jsfa.4152

Phesatcha, B., M. Wanapat, K. Phesatcha, T. Ampapon, \& S. Kang. 2016. Supplementation of Flemingia macrophylla and cassava foliage as a rumen enhancer on fermentation efficiency and estimated methane production in dairy steers. Trop. Anim. Health Prod. 48:1449-1454. https://doi.org/ 10.1007/s11250-016-1115-5

Poungchompu, O., M. Wanapat, C. Wachirapakorn, S. Wanapat, \& A. Cherdthong. 2009. Manipulation of ruminal fermentation and methane production by dietary saponins and tannins from mangosteen peel and soapberry fruit. Arch. Anim. Nutr. 63:389-400. https://doi. org/10.1080/17450390903020406

Ramírez-Avilés, L., F. J. Solorio-Sánchez, C. F. Aguilar-Pérez, A. J. Ayala-Burgos, \& J. C. Ku-Vera. 2019. Leucaena leucocephala feeding systems for cattle production in Mexico. Trop. grassl.-Forrajes trop. 7:375-380. https://doi. org/10.17138/tgft(7)375-380

Russell, J. B., R. E. Muck, \& P. J. Weimer. 2009. Quantitative 
analysis of cellulose degradation and growth of cellulolytic bacteria in the rumen. FEMS. Microbiol. Ecol. 67: 183197. https://doi.org/10.1111/j.1574-6941.2008.00633.x

SAS. 2013. Statistical Analysis System, User's Guide: Statistic. Version 9. $4^{\text {th }}$ Ed. SAS Inst. Inc., Cary, NC.

Satter, L. D. \& L. L. Slyter. 1974. Effect of ammonia concentration on rumen microbial protein production in vitro. Br. J. Nutr. 32:199-208. https://doi.org/10.1079/bjn19740073

Tavendale, M. H., L. P. Meagher, D. Pacheco, N. Walker, G. T. Attwood, \& S. Sivakumaran. 2005. Methane production from in vitro rumen incubations with Lotus pedunculatus and Medicago sativa, and effects of extractable condensed tannin fractions on methanogenesis. Anim. Feed Sci. Technol. 123:403-419. https://doi.org/10.1016/j. anifeedsci.2005.04.037

Teferedegne, B. 2000. New perspectives on the use of tropical plants to improve ruminant nutrition. Proc. Nutr. Soc. 59:209-214. https://doi.org/10.1017/s0029665100000239.

Turner, K. E., S, Wildeus, \& J. R. Collins. 2005. Intake, performance, and blood parameters in young goats offered high forage diets of lespedeza or alfalfa hay. Small Rumin. Res. 59:15-23. https://doi.org/10.1016/j.smallrumres.2004.11.007

Van Keulen, J. Y. B. A. \& B. A. Young. 1977. Evaluation of acidinsoluble ash as a natural marker in ruminant digestibility studies. J. Anim. Sci. 44:282-287. https://doi.org/10.2527/ jas1977.442282x

Van Soest, P. V., J. B. Robertson, \& B. A. Lewis. 1991. Methods for dietary fiber, neutral detergent fiber, and nonstarch polysaccharides in relation to animal nutrition. J. Dairy Sci. 74:3583-3597. https://doi.org/10.3168/jds. S0022-0302(91)78551-2

Viennasay, B. \& M. Wanapat. 2020. Enhancing lactating dairy cow rumen fermentation and production with Flemingia silage containing phytonutrients. Livest. Sci. 241:104201. https://doi.org/10.1016/j.livsci.2020.104201
Wanapat, M. \& O. Pimpa. 1999. Effect of ruminal $\mathrm{NH}_{3}-\mathrm{N}$ levels on ruminal fermentation, purine derivatives, digestibility and rice straw intake in swamp buffaloes. AsianAustralas. J. Anim. Sci. 12:904-907. https://doi.org/10.5713/ ajas.1999.904

Wanapat, M., T. Puramongkon, \& W. Siphuak. 2000. Feeding of cassava hay for lactating dairy cows. Asian-Australas. J. Anim. Sci. 13:478-82. https://doi.org/10.5713/ajas.2000.478

Wanapat, M. 2009. Potential uses of local feed resources for ruminants. Trop. Anim. Health Prod. 41:1035-1049. https:// doi.org/10.1007/s11250-008-9270-y

Wanapat, M., P. Kongmun, O. Poungchompu, A. Cherdthong, P. Khejornsart, R. Pilajun, \& S. Kaenpakdee. 2012. Effects of plants containing secondary compounds and plant oils on rumen fermentation and ecology. Trop. Anim. Health Prod. 44:399-405. https://doi.org/10.1007/s11250-011-9949-3

Wanapat, M., S. Kang, \& S. Polyorach. 2013. Development of feeding systems and strategies of supplementation to enhance rumen fermentation and ruminant production in the tropics. J. Anim. Sci. Biotechnol. 4:32. https://doi. org/10.1186/2049-1891-4-32

Wang, J. K., J. A. Ye, \& J. X. Liu. 2012. Effects of tea saponins on rumen microbiota, rumen fermentation, methane production and growth performance-a review. Trop. Anim. Health Prod. 44:697-706.

Wang, S., M. Terranova, M. Kreuzer, S. Marquardt, L. Eggerschwiler, \& A. Schwarm. 2018. Supplementation of pelleted hazel (Corylus avellana) leaves decreases methane and urinary nitrogen emissions by sheep at unchanged forage intake. Sci. Rep. 8:1-10. https://doi.org/10.1038/ s41598-018-23572-3

Weiss, W. P., N. R. St-Pierre, \& L. B. Willett. 2009. Varying type of forage, concentration of metabolizable protein, and source of carbohydrate affects nutrient digestibility and production by dairy cows. J. Dairy Sci. 92:5595-5606. https://doi.org/10.3168/jds.2009-2247 